\title{
REFERENCES
}

Carpenter, K. J. (1958a). Proc. Nutr. Soc. 17, 91.

Carpenter, K. J. (1958b). Voeding, I9, 152.

Carpenter, K. J. \& Ellinger, G. M. (1955). Biochem. F. 6r, xi.

Carpenter, K. J., Ellinger, G. M., Munro, M. I. \& Rolfe, E. J. (1957). Brit. F. Nutr. Ir, I62.

Eldred, N. R. \& Rodney, G. (r946). F. biol. Chem. 162, 26 r.

Henderson, L. M. \& Snell, E. E. (1948). F. biol. Chem. 172, 5.

Kay, H. D. (1939-40). Nutr. Abstr. Rev. 9, I.

Keeney, M. \& Bassette, R. (1957). Science, 126, 5 I I.

Lea, C. H. \& Hannan, R. S. (1950). Biochem. biophys. Acta, 5, 433.

Milk Nutrition Committee (1937). Milk and Nutrition. Part I. The Effect of Commercial Pasteurisation on the Nutritive Value of Milk, as Determined by Laboratory Experiment, p. 37. Reading: National Institute for Research in Dairying.

Mauron, J., Mottu, F., Bujard, E. \& Egli, R. H. (1955). Arch. Biochem. Biophys. 59, 433.

Moore, S. \& Stein, W. (1951). F. biol. Chem. 192, 663.

Schram, E., Dustin, J. P., Moore, S. \& Bigwood, E. J. (1953). Analyt. chim. acta, 9, 149.

Schram, E., Moore, S. \& Bigwood, E. J. (1954). Biochem. F. 57, 33.

\section{Some blood coagulation studies in normal and scorbutic guinea-pigs}

\author{
BY P. BARKHAN \\ Department of Medicine, University of Cambridge \\ AND A. N. HOWARD \\ Dunn Nutritional Laboratory, University of Cambridge and \\ Medical Research Council
}

(Received 3 Fanuary 1959-Revised 9 May 1959)

Haemorrhage is a feature of severe ascorbic-acid deficiency in both primates and guinea-pigs. The scorbutic picture in man is usually accompanied by a deficiency of other vitamins and nutrients, and the haemorrhagic state may reflect more than a lack of ascorbic acid. There is much evidence to indicate a capillary abnormality in scurvy (Findlay, I921; Wolbach \& Howe, I926; Wolbach \& Bessey, 1942; Lee \& Lee, 1947), and the haemorrhage is generally believed to result from this vascular alteration. Other evidence indicates some change in the blood-clotting mechanism. Sullivan, Gangstad \& Link (1943) observed a prolonged one-stage prothrombin time with scorbutic guinea-pig plasma. This finding was confirmed by Marx \& Bayerle (1943), who in addition found an increase in the fibrinogen concentration. Both abnormalities disappeared after the administration of ascorbic acid.

To our knowledge there is no information of possible changes at the thromboplastic level of blood coagulation. In guinea-pigs, which we have used in these experiments, it is possible to produce a pure ascorbic-acid deficiency under controlled conditions. We have therefore studied some aspects of the coagulation mechanism in scorbutic and normal guinea-pigs with a view to extending the observations of these earlier workers. 
METHODS

\section{Animals and diet}

Male guinea-pigs of about $250 \mathrm{~g}$ body-weight were obtained from Allington Farm, Ministry of Supply, Porton, Wilts, and fed initially on the semisynthetic diet no. I 3 described by Reid \& Briggs (I953). Vitamins A, D, E and $\mathrm{K}$ were not mixed in the diet, but were provided by two drops of halibut-liver oil, four drops of a solution of $\alpha$-tocopheryl acetate $(5 \%(\mathrm{w} / \mathrm{v})$ in arachis oil) and two drops of a solution of 2 -methyl$\mathrm{I}, 4$-naphthoquinone $(0.25 \%(\mathrm{w} / \mathrm{v})$ in arachis oil) given orally to each animal once weekly. The diet contained $2 \mathrm{~g}$ ascorbic acid $/ \mathrm{kg}$ and the normal intake of ascorbic acid was $50-70 \mathrm{mg} /$ day.

\section{Avitaminosis C}

On reaching $300 \mathrm{~g}$ body-weight guinea-pigs were placed in one of two groups. A scorbutic group was fed on the diet just described with the ascorbic acid omitted; a normal control group was allowed to continue on the complete diet. On the scorbutogenic diet guinea-pigs grew normally for the first 10-12 days and then lost weight. Death usually occurred after 22-28 days when the animals reached a body-weight of I90 g. Animals for coagulation studies were killed at various stages of the deficiency but no moribund animals (less than $200 \mathrm{~g}$ body-weight) were used. The food intake dropped progressively after IO-I2 days to about one-third of the intake of normal animals. It was considered, however, that no deficiency other than that of vitamin $\mathrm{C}$ developed during the experimental period.

\section{Hypovitaminosis $C$}

Another series of guinea-pigs was placed on the scorbutogenic diet, and after ro days dosed with different levels of ascorbic acid for 3 months. The dose levels given were $0.4,0.8$ or $1.6 \mathrm{mg} /$ day in $1 \%(\mathrm{w} / \mathrm{v})$ citric acid. Some animals received the equivalent dose only three times or twice a week. Guinea-pigs receiving $\mathrm{I} \cdot 6 \mathrm{mg} /$ day showed normal growth (mean $480 \mathrm{~g} / \mathrm{I} 20$ days); with $0.8 \mathrm{mg} /$ day growth was retarded (mean $200 \mathrm{~g} / \mathrm{I} 20$ days); those receiving $0.4 \mathrm{mg} /$ day did not grow but just maintained their body-weight.

\section{Collection and treatment of blood}

The chest and abdominal cavities were opened under deep ether anaesthesia. The supra-diaphragmatic portion of the inferior vena cava was exposed and blood aspirated from it with a no. 20 B.D. steel needle and an all-glass paraffined syringe. It was generally possible to obtain $5^{-10} \mathrm{ml}$ blood in this way, although in some of the scorbutic animals, owing to their small body-weight, only less could be aspirated. One portion of the blood was citrated (for plasma) by transferring it to a siliconed glass tube containing a volume of a solution of trisodium citrate $\left(3^{8} \mathrm{~g} / \mathrm{l}\right.$.) equal to one-tenth the volume of the blood and gently mixing the contents. Another portion was allowed to clot at $37^{\circ}$ for several hours and the serum separated. Both plasma and serum were used fresh whenever possible, but many samples were stored at $-20^{\circ}$ for several days or weeks before testing. 


\section{Coagulation techniques}

Platelet count. The direct method described previously (Barkhan, 1957) was used.

Clot retraction and lysis. A visual inspection was made after incubation of the clotted blood in glass tubes for $\mathrm{I}-3 \mathrm{~h}$ at $37^{\circ}$. Lysis was determined by inspection of the clot for dissolution.

Plasma one-stage prothrombin time. (a) Method of Quick (1939). The thromboplastin was prepared from normal guinea-pig brains. (b) Stypven method. The method used was that described by Barkhan, Tomlin \& Archer (1957). Russell's viper venom (Stypven preparation of Burroughs Wellcome Ltd) was used as thromboplastin, and guinea-pig brain lipid as venom cofactor.

Blood thromboplastin formation. It was measured by the method of Biggs \& Douglas (1953) as modified by Bell \& Alton (1954). For convenience, brain lipid of constant composition was used instead of platelet suspensions in all assays unless platelet activity was to be tested. The lipid material (platelet substitute) was prepared from normal guinea-pig brain. Reagents were diluted about $\mathrm{I} h$ before being tested. Since maximum thromboplastic activity was generated within $6 \mathrm{~min}$ in almost all instances, the test was usually not carried out beyond that time. The ist min reading was not recorded as the amount of thromboplastin formed after $\mathrm{I}$ min was usually negligible.

Antiheparin activity. The test systems consisted of $0 \cdot \mathrm{I} \mathrm{ml}$ normal platelet-poor plasma, $0.1 \mathrm{ml}$ saline or platelet suspension (approximately $\mathrm{I}^{\cdot} 5 \times 10^{6} / \mathrm{mm}^{3}$ ), $\mathrm{O}^{\circ} \mathrm{I} \mathrm{ml}$ saline or heparin $(0.1 \mu \mathrm{g})$ and $0.1 \mathrm{ml}$ thrombin ( 2 units of the material supplied by the Lister Institute for Preventive Medicine, London).

Terminology. The nomenclature used for the various coagulation factors and activities is that of Biggs \& McFarlane (1957).

\section{RESULTS}

Except where specified, the results quoted for scorbutic blood refer to those from guinea-pigs fed on the diet free from ascorbic acid for 17-23 days. Adsorbed plasma refers to plasma adsorbed on aluminium hydroxide.

\section{Clot reaction and lysis}

Samples from the normal and the scorbutic animals appeared to retract equally well and the clots maintained their integrity at $37^{\circ}$ for at least $5 \mathrm{~h}$ after formation, which excluded any gross defect in clot retraction and lysis in the blood of scorbutic guineapigs. On the assumption that there is no qualitative change in the platelets of scorbutic animals, their clot retraction might be expected to be even better than normal because of the increased platelet concentration (see below); this difference would not necessarily be evident from visual inspection.

\section{Platelet count}

A significant increase $(50-80 \%)$ in the whole-blood platelet count was found in animals receiving no ascorbic acid, $0.4 \mathrm{mg} /$ day, or $0.8 \mathrm{mg} /$ day dosed twice weekly 
(Table I). In the group completely deprived of ascorbic acid there was an increase after only ro days. Animals receiving $1.6 \mathrm{mg} /$ day, or $0.8 \mathrm{mg} /$ day dosed daily or thrice weekly did not differ significantly from controls receiving $60 \mathrm{mg} / \mathrm{day}$.

\section{Plasma one-stage prothrombin time}

With brain thromboplastin. Plasma prothrombin times were lengthened by $25 \%$ in guinea-pigs kept on a diet free from ascorbic acid for 19-24 days (Table 1 ). No significant change was observed in animals deprived of ascorbic acid for 10 days or dosed with amounts higher than $0.4 \mathrm{mg} /$ day.

Table I. Effect of ascorbic-acid intake on the whole-blood platelet count and plasma one-stage prothrombin times in guinea-pigs

\begin{tabular}{|c|c|c|c|c|c|c|c|}
\hline \multirow{2}{*}{$\begin{array}{l}\text { Mean } \\
\text { ascorbic- } \\
\text { acid } \\
\text { intake } \\
\text { (mg/day) }\end{array}$} & \multirow{2}{*}{$\begin{array}{c}\text { Frequency } \\
\text { of } \\
\text { of dosing }\end{array}$} & \multirow[b]{2}{*}{$\begin{array}{c}\text { No. of } \\
\text { days }\end{array}$} & \multirow[b]{2}{*}{$\begin{array}{l}\text { No. of } \\
\text { animals }\end{array}$} & \multirow{2}{*}{$\begin{array}{c}\text { Platelets } \dagger \\
\left(\times 10^{-3} / \mathrm{mm}^{3}\right)\end{array}$} & \multirow{2}{*}{$\begin{array}{l}\text { Prothrombin } \\
\text { timet } \\
\text { (sec) }\end{array}$} & \multicolumn{2}{|c|}{$\begin{array}{l}\text { Percentage difference } \\
\text { from normal animals }\end{array}$} \\
\hline & & & & & & Platelets & $\begin{array}{l}\text { Prothrombin } \\
\text { time }\end{array}$ \\
\hline 60 & Daily & I9-24 & 8 & $491 \pm 39$ & $26 \cdot 1 \pm 0.6$ & 一 & -- \\
\hline$I \cdot 6$ & Daily & $100-120$ & 8 & $476 \pm 3^{8}$ & $26 \cdot 6 \pm 0.6$ & -3 & +2 \\
\hline 0.8 & Daily & $100-120$ & 5 & $428 \pm 28$ & $24 \cdot 2 \pm 0.7$ & -13 & -7 \\
\hline 0.8 & $\begin{array}{l}\text { Thrice } \\
\text { weekly }\end{array}$ & $100-120$ & 3 & $559 \pm 25$ & $26 \cdot 2 \pm 0 \cdot 5$ & +10 & +4 \\
\hline 0.8 & $\begin{array}{l}\text { Twice } \\
\text { weekly }\end{array}$ & $100-120$ & 4 & $755 \pm 47^{* *}$ & $26 \cdot 0 \pm 0.7$ & +54 & -4 \\
\hline 0.4 & Daily & $100-120$ & 2 & $733 \pm 119^{*}$ & $29.5 \pm 0.5^{*}$ & +49 & +13 \\
\hline$\circ$ & - & IO & 5 & $900 \pm 177^{*}$ & $28 \cdot 2 \pm 0.4$ & +83 & +8 \\
\hline$\circ$ & - & $19^{-24}$ & 8 & $870 \pm 76 * * *$ & $32 \cdot 7 \pm I \cdot 5^{* * *}$ & +77 & +25 \\
\hline
\end{tabular}

Table 2. Effect of saline, and of serum and adsorbed plasma from normal guinea-pigs, on the plasma one-stage prothrombin times of scorbutic guinea-pigs

\begin{tabular}{cccc} 
Plasma & \multicolumn{3}{c}{ Prothrombin time (sec) } \\
sample no. & Saline & $\begin{array}{c}\text { Adsorbed } \\
\text { plasma }\end{array}$ & Serum \\
I & 32 & 36 & 28 \\
2 & 34 & 38 & 30 \\
3 & 33 & 32 & 27 \\
4 & 35 & 35 & 27 \\
5 & 44 & 48 & 32
\end{tabular}

A few samples of plasma from scorbutic guinea-pigs with rather prolonged prothrombin times were further examined for the effect of adding either serum or adsorbed plasma from normal guinea-pigs to the test system (Table 2). Only the addition of serum shortened the clotting times to within the normal range. When serum was added to plasma from normal animals, the plasma prothrombin time was usually unaltered, but with some specimens it was shortened by $\mathrm{r}-2$ sec.

With Stypven. Plasma from four scorbutic guinea-pigs showing lengthened plasma 
prothrombin times with brain thromboplastin was further examined with Stypven (Table 3). The clotting times were somewhat lengthened when no lipid cofactor was added. With lipid, however, the plasma from scorbutic animals was as active as that from normal ones.

Table 3. Mean values with their standard errors for Stypven clotting times of plasma from normal and scorbutic guinea-pigs

$\begin{array}{lccc}\text { No. of } & \begin{array}{c}\text { Saline } \\ \text { animals }\end{array} & \begin{array}{c}\text { Lipid } \\ \text { Source of plasma }\end{array} \\ \begin{array}{l}\text { Normal animals } \\ \text { Scorbutic animals }\end{array} & 3 & \begin{array}{l}\mathbf{1 2} \cdot 7 \pm 0.2 \\ 14 \cdot 8 \pm 0.4 * *\end{array} & \begin{array}{l}7 \cdot 0 \pm 0.3 \\ 6 \cdot 6 \pm 0.4\end{array} \\ & * * 0 \cdot 01>P>0.001 . & \end{array}$

Effect of ascorbic acid and vitamin $K$. To investigate whether ascorbic acid was involved per se in the plasma prothrombin times, ascorbic acid was added to plasma from scorbutic guinea-pigs to achieve a normal physiological concentration $(0 \cdot 01 \mathrm{mg} /$ $\mathrm{ml}$ ), and plasma was also taken from scorbutic guinea-pigs injected intramuscularly with ascorbic acid $\left(0^{\cdot} 5^{-1} \cdot \circ \mathrm{g}\right.$ neutralized with $\left.\mathrm{NaHCO}_{3}\right)$ I h before blood was taken. No shortening of the plasma prothrombin times was noted (Table 4), which indicates that ascorbic acid had no direct effect on prothrombin activity.

Table 4. Plasma one-stage prothrombin times and whole-blood platelet counts of scorbutic guinea-pigs injected with ascorbic acid shortly before they were bled and killed or with vitamin $K$ several days before

\begin{tabular}{|c|c|c|c|}
\hline $\begin{array}{c}\text { Animal } \\
\text { no. }\end{array}$ & $\begin{array}{l}\text { Vitamin } \\
\text { injected }\end{array}$ & $\begin{array}{l}\text { Prothrombin } \\
\text { time }(\mathrm{sec})\end{array}$ & $\begin{array}{c}\text { Platelets } \\
\left(\times 10^{-3} / \mathrm{mm}^{3}\right)\end{array}$ \\
\hline $\left.\begin{array}{l}1 \\
2 \\
3\end{array}\right\}$ & $\mathrm{C}$ & $\left\{\begin{array}{l}32 \\
32 \\
32\end{array}\right.$ & $\frac{866}{828}$ \\
\hline $\left.\begin{array}{l}4 \\
5 \\
6\end{array}\right\}$ & $\mathrm{K}$ & $\left\{\begin{array}{l}3^{8} \\
34 \\
30\end{array}\right.$ & $\begin{array}{r}813 \\
897 \\
1880\end{array}$ \\
\hline
\end{tabular}

As prolonged prothrombin times also occur in vitamin $\mathrm{K}$ deficiency, it was thought that the prolonged clotting times of plasma from scorbutic animals might be caused by a conditioned deficiency of vitamin $\mathrm{K}$, which might occur if the intestinal absorption of vitamin $\mathrm{K}$ is impaired in scurvy. Vitamin $\mathrm{K}$ (100 $\mu \mathrm{g}$ sodium 2-methyl-1,4naphthohydroquinone diphosphate in $0.1 \mathrm{ml}$ saline) was therefore injected intramuscularly into scorbutic guinea-pigs for several days before they were bled and killed. The treatment had no effect on the plasma prothrombin times, which indicates that vitamin $\mathrm{K}$ was not involved (Table 4).

As was expected, the administration of ascorbic acid $\mathrm{I} h$ before death and of vitamin $\mathrm{K}$ for several days produced no change in the elevated whole-blood platelet count (Table 4). 


\section{Blood thromboplastin activity}

Normal animals. Components from normal guinea-pig blood used for thromboplastin formation behaved like those from man and would substitute for human components. Human thromboplastin also reacted as well with guinea-pig plasma as with human plasma. Clotting times when guinea-pig thromboplastin was added to human plasma were, however, slightly longer $(\mathrm{I}-2 \mathrm{sec})$ than when it was added to guinea-pig plasma.

The thromboplastic activity of blood from normal guinea-pigs (animals receiving $60 \mathrm{mg}$ ascorbic acid/day) is shown in Table 5 . The mean minimum clotting time was I $1.9 \mathrm{sec}$, reached after $3-4 \mathrm{~min}$ incubation. When a normal incubation mixture with minimum substrate clotting time of $\mathrm{I} 2 \mathrm{sec}$ was diluted $\mathrm{I}: \mathrm{I}, \mathrm{I}: 3$ or $\mathrm{I}: 4$ with saline, the clotting times were 15,19 and $25 \mathrm{sec}$ respectively. In the absence of lipid or platelets, minimum clotting times were generally about $25 \mathrm{sec}$ or more and were reached after longer periods of incubation (8-10 min).

Table 5. Thromboplastic activity of serum and adsorbed plasma from normal and scorbutic guinea-pigs

\begin{tabular}{|c|c|c|c|c|c|c|c|c|c|}
\hline \multirow[b]{3}{*}{$\begin{array}{l}\text { Group } \\
\text { no. }\end{array}$} & \multirow{3}{*}{$\begin{array}{c}\text { Mean } \\
\text { ascorbic- } \\
\text { acid } \\
\text { intake } \\
\text { (mg/day) }\end{array}$} & \multirow{3}{*}{$\begin{array}{l}\text { No. of } \\
\text { days }\end{array}$} & \multirow{3}{*}{$\begin{array}{l}\text { No. of } \\
\text { animals }\end{array}$} & \multicolumn{6}{|c|}{ Substrate clotting time (mean value and range) (sec) } \\
\hline & & & & \multicolumn{5}{|c|}{ Incubation time } & \multirow[b]{2}{*}{ Minimum } \\
\hline & & & & $2 \min$ & $3 \mathrm{~min}$ & $4 \mathrm{~min}$ & $5 \mathrm{~min}$ & $6 \mathrm{~min}$ & \\
\hline $\mathbf{r}$ & 60 & $19-24$ & 29 & $\begin{array}{c}18 \\
(10.5-33)\end{array}$ & $\begin{array}{c}14 \\
\left(10 \cdot 5^{-25}\right)\end{array}$ & $\begin{array}{c}12.5 \\
\left(9^{-5}-19 \cdot 5\right)\end{array}$ & $\begin{array}{c}13 \\
(10-21)\end{array}$ & $\begin{array}{c}13.5 \\
(10.5-2 I)\end{array}$ & $\begin{array}{c}11 \cdot 9 \\
\left(9^{-1} 5^{-14} \cdot 5\right)\end{array}$ \\
\hline 2 & $\mathbf{1} \cdot 6$ & $100-120$ & 4 & $\begin{array}{c}19.5 \\
(13-30)\end{array}$ & $\begin{array}{c}14 \\
(I I-2 I)\end{array}$ & $\begin{array}{l}12.5 \\
(11-15.5)\end{array}$ & $\begin{array}{c}\text { I2.5 } \\
\text { (II.5-14.5) }\end{array}$ & - & $\begin{array}{c}1 I * 9 \\
(I I-I 4)\end{array}$ \\
\hline 3 & 0.8 & $100-120$ & 12 & $\begin{array}{c}26 \\
(16-37)\end{array}$ & $\begin{array}{c}I 8 \\
(\mathrm{x} 1-25)\end{array}$ & $\begin{array}{c}14^{*} 5 \\
(1 \mathrm{I}-22)\end{array}$ & $\begin{array}{c}15 \\
(1 \mathrm{I}-23)\end{array}$ & $\begin{array}{c}15 \\
(10.5-17.5)\end{array}$ & $\begin{array}{c}12 \cdot 8 \\
(10 \cdot 5-16.5)\end{array}$ \\
\hline 4 & 0.4 & $100-120$ & 2 & $\begin{array}{c}20 \\
(17 \cdot 5-23)\end{array}$ & $\begin{array}{c}18 \\
(16-20)\end{array}$ & $\begin{array}{c}16 \\
(15-x 7)\end{array}$ & $\begin{array}{c}16.5 \\
(15.5-17.5)\end{array}$ & $\begin{array}{c}18.5 \\
(18-19)\end{array}$ & $\begin{array}{c}16.0 \\
(15-17)\end{array}$ \\
\hline 5 & ○ & ro & $\mathbf{5}$ & + & + & + & $t$ & $t$ & $\begin{array}{l}15.8 * * * \\
(14-18)\end{array}$ \\
\hline 6 & $\circ$ & $19-24$ & 18 & $\begin{array}{c}24 \\
(12 \cdot 5-45)\end{array}$ & $\begin{array}{c}19 \\
(12 \cdot 5-37)\end{array}$ & $\begin{array}{c}18 \\
(\mathrm{I} \cdot 5-37)\end{array}$ & $\begin{array}{c}18 \\
(12 \cdot 5-37)\end{array}$ & $\begin{array}{c}20 \\
(13-37)\end{array}$ & $\begin{array}{r}17 \cdot 0 * * * \\
(11 \cdot 5-37)\end{array}$ \\
\hline
\end{tabular}

Animals with different levels of ascorbic-acid intake. As shown in Table 5, animals receiving $0.8 \mathrm{mg}$ or more ascorbic acid daily had thromboplastic activities approximately the same as controls receiving $60 \mathrm{mg} /$ day. Those receiving $0.4 \mathrm{mg} /$ day or no ascorbic acid showed reduced thromboplastic activity, and a difference was seen after only ro days of complete deficiency. Animals on a completely deficient diet for 19-24 days had a mean minimum clotting time of $17^{\circ} 0$ sec compared with II. 9 sec for normal animals. If it is assumed that a clotting time of $11.9 \mathrm{sec}$ represents $100 \%$ thromboplastin formation, $17 \mathrm{sec}$ would represent $25-50 \%$ of normal. Although the difference was highly significant $(P<0.001)$ there was a wide scatter of values and about $50 \%$ of these scorbutic animals had values in the normal range. All had haemorrhages in the muscles adjacent to the knee joints (but not intra-articular), and some had blood in the caecal lumen. It was not possible therefore to correlate the extent of the haemorrhage and thromboplastic activity. But it should be noted that many of the 
specimens were stored at $-20^{\circ}$ for variable periods and could have improved on storage as is known to occur in the plasma thromboplastin antecedent (PTA) syndrome (Rosenthal, Dreskin \& Rosenthal, I955).

Separate assay of plasma and serum from scorbutic guinea-pigs. To find whether the defect in thromboplastin formation was due to factors in the plasma or serum, plasma and serum from fourteen scorbutic animals were assayed with serum and adsorbed plasma from normal animals respectively. The results are shown in Table 6. Serum from normal and adsorbed plasma from scorbutic animals gave a system significantly more active $(0.05>P>0.01)$ than when both were from scorbutic animals, but the mean minimum clotting time was still longer than normal. Plasma from normal animals added to serum from scorbutic ones gave a lower mean clotting time than when both were from scorbutic animals, but the difference was not significant $(P>0.05)$. It is to be noted, however, that out of the fourteen systems examined eight showed a reduction in clotting time greater than or equal to I sec, the remainder being unchanged. It was therefore concluded that there was a deficiency of a factor or factors in both serum and adsorbed plasma.

Effect of ascorbic acid and vitamin $K$. Ascorbic acid in vitro $(0 \cdot 0 \mathrm{I} \mathrm{mg} / \mathrm{ml}$ test system), or given by injection $\mathrm{I} h$ before the animals were bled and killed or vitamin

Table 6. Thromboplastic activity of serum and adsorbed plasma from scorbutic guineapigs assayed respectively with adsorbed plasma and serum from normal guinea-pigs

(Brain lipid was used throughout as platelet substitute)

\begin{tabular}{|c|c|c|c|}
\hline \multirow[b]{2}{*}{ Animal no. } & \multicolumn{3}{|c|}{ Minimum substrate clotting times (sec) } \\
\hline & $\begin{array}{l}\text { Group r. } \\
\text { Serum + adsorbed } \\
\text { plasma from } \\
\text { scorbutic } \\
\text { animals }\end{array}$ & $\begin{array}{l}\text { Group 2. Serum } \\
\text { from scorbutic } \\
\text { animals + adsorbed } \\
\text { plasma } \\
\text { from } \\
\text { normal ones }\end{array}$ & $\begin{array}{c}\text { Group 3. Adsorbed } \\
\text { plasma } \\
\text { from scorbutic } \\
\text { animals }+ \text { serum } \\
\text { from } \\
\text { normal ones }\end{array}$ \\
\hline $\mathbf{I}$ & 21 & 21 & 14.5 \\
\hline 2 & 16 & I6 & 14 \\
\hline 3 & 21 & 20 & I 5 \\
\hline 4 & 37 & 17 & $16 \cdot 5$ \\
\hline 5 & 17 & I7 & 14 \\
\hline 6 & 14 & $13 \cdot 5$ & 13.5 \\
\hline 7 & 14.5 & I3 & 13.5 \\
\hline 8 & 16.5 & 15 & 12 \\
\hline 9 & 14.5 & 12 & 14 \\
\hline IO & 14 & I4 & 15 \\
\hline I I & 14 & 14 & $14 \cdot 5$ \\
\hline 12 & 12 & $10 \cdot 5$ & 10.5 \\
\hline 13 & $r_{5}$ & 13 & $I I \cdot 5$ \\
\hline 14 & I6 & 13 & 12 \\
\hline Mean & $17 \cdot 3$ & $14^{\circ} 9$ & $13 \cdot 6$ \\
\hline
\end{tabular}

Group 4. Adsorbed plasma + serum from twenty-nine normal animals (see Table 5), mean value $=11 \cdot 9$.

Statistical comparison of groups

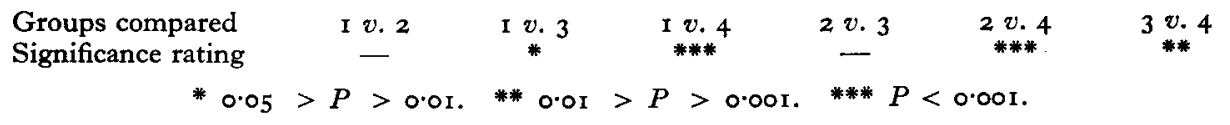


Table 7. Effect of injection of ascorbic acid shortly before death or vitamin $K$ for several days before death on the thromboplastic activity of serum and adsorbed plasma from scorbutic guinea-pigs

\begin{tabular}{|c|c|c|c|c|c|c|}
\hline \multirow{3}{*}{$\begin{array}{l}\text { Vitamin } \\
\text { injected }\end{array}$} & \multirow{3}{*}{$\begin{array}{c}\text { No. of } \\
\text { animals }\end{array}$} & \multicolumn{5}{|c|}{ Substrate clotting time (mean value and range) (sec) } \\
\hline & & \multicolumn{4}{|c|}{ Incubation time } & \multirow[b]{2}{*}{ Minimum } \\
\hline & & $2 \mathrm{~min}$ & $3 \mathrm{~min}$ & $4 \min$ & $5 \mathrm{~min}$ & \\
\hline None & I 8 & $\begin{array}{c}24 \\
\left(12 \cdot 5^{-45}\right)\end{array}$ & $\begin{array}{c}19 \\
(12 \cdot 5-37)\end{array}$ & $\begin{array}{c}18 \\
(1 \mathrm{I} \cdot 5-37)\end{array}$ & $\begin{array}{c}18 \\
(12 \cdot 5-37)\end{array}$ & $\begin{array}{c}17 \\
(11 \cdot 5-37)\end{array}$ \\
\hline C & 3 & $\begin{array}{c}23.5 \\
(15.5-40)\end{array}$ & $\begin{array}{c}19.5 \\
(14.5-26)\end{array}$ & $\begin{array}{c}17 \\
(15.5-19.5)\end{array}$ & $\begin{array}{c}17.5 \\
(16.0-19.5)\end{array}$ & $\begin{array}{c}16 \\
(14.5-16.5)\end{array}$ \\
\hline $\mathrm{K}$ & 2 & $\begin{array}{c}34 \\
(30-38)\end{array}$ & $\begin{array}{c}23 \\
(23)\end{array}$ & $\begin{array}{c}19 \cdot 5 \\
(22-24)\end{array}$ & $\begin{array}{c}19 \cdot 5 \\
(18-21)\end{array}$ & $\begin{array}{c}19.5 \\
(18-21)\end{array}$ \\
\hline
\end{tabular}

Table 8. Effect of ascorbic acid in vitro on the thromboplastic activity of serum and adsorbed plasma from scorbutic guinea-pigs

\begin{tabular}{|c|c|c|c|c|c|}
\hline \multirow{2}{*}{$\begin{array}{c}\text { Animal } \\
\text { no. }\end{array}$} & \multirow{2}{*}{$\begin{array}{l}\text { Addition to } \\
\text { test system }\end{array}$} & \multicolumn{4}{|c|}{$\begin{array}{l}\text { Substrate clotting time (sec) } \\
\text { Incubation time }\end{array}$} \\
\hline & & $2 \mathrm{~min}$ & $3 \mathrm{~min}$ & $4 \mathrm{~min}$ & $5 \mathrm{~min}$ \\
\hline I & $\begin{array}{l}\text { Saline } \\
\text { Ascorbic acid }\end{array}$ & $\begin{array}{l}34 \\
34\end{array}$ & $\begin{array}{l}24 \\
20\end{array}$ & $\begin{array}{l}\text { I6 } \\
\text { I5 }\end{array}$ & $\begin{array}{l}16 \\
16\end{array}$ \\
\hline 2 & $\begin{array}{l}\text { Saline } \\
\text { Ascorbic acid }\end{array}$ & $\begin{array}{l}33 \\
40\end{array}$ & $\begin{array}{l}26 \\
26\end{array}$ & $\begin{array}{l}29 \\
28\end{array}$ & $\begin{array}{l}29 \\
35\end{array}$ \\
\hline 3 & $\begin{array}{l}\text { Saline } \\
\text { Ascorbic acid }\end{array}$ & $\begin{array}{l}25 \\
46\end{array}$ & $\begin{array}{l}24 \\
26\end{array}$ & $\begin{array}{l}22 \\
22\end{array}$ & $\begin{array}{l}24 \\
22\end{array}$ \\
\hline 4 & $\begin{array}{l}\text { Saline } \\
\text { Ascorbic acid }\end{array}$ & $\begin{array}{l}29 \\
31\end{array}$ & $\begin{array}{l}22 \\
24\end{array}$ & $\begin{array}{l}25 \\
22\end{array}$ & $\begin{array}{l}27 \\
29\end{array}$ \\
\hline
\end{tabular}

$\mathrm{K}$ injected for several days before (as described in the section on prothrombin times), produced no improvement in the thromboplastic activity of adsorbed plasma and serum from scorbutic animals (Tables 7 and 8 ).

Thromboplastic activity of platelets from normal and scorbutic animals

Serum and adsorbed plasma from five scorbutic animals, showing clearly subnormal thromboplastic activities with brain lipid, were further tested by replacing it with platelets from normal or scorbutic animals (Table 9). Somewhat greater activity was found in the platelet-containing systems, although total activity was still relatively low. In this respect platelets from scorbutic animals did not differ from those from normal ones.

On several occasions the reaction between platelets from normal and scorbutic animals and serum and adsorbed plasma from normal animals was studied, the same serum and adsorbed plasma being used for each comparison. The results (Table 10) showed that platelets from scorbutic animals were as active as those from normal ones.

The antiheparin activity of pooled platelets from normal animals and from scorbutic ones was examined as shown in Table I I. No differences were observed between those from scorbutic and normal animals. 
Table 9. Comparison of thromboplastic activities of serum and adsorbed plasma from scorbutic guinea-pigs assayed with brain lipid or with platelets from scorbutic or normal guinea-pigs

(Five animals/group. Concentration of platelets in the incubation mixture approximately $350000 / \mathrm{mm}^{3}$ )

\section{Addition to serum and adsorbed plasma from scorbutic animals \\ Brain lipid}

Platelets from scorbutic animals

Platelets from normal animals

\begin{tabular}{|c|c|c|c|c|}
\hline \multicolumn{4}{|c|}{ Incubation time } & \multirow[b]{2}{*}{ Minimum } \\
\hline $2 \mathrm{~min}$ & $3 \mathrm{~min}$ & $4 \mathrm{~min}$ & $5 \mathrm{~min}$ & \\
\hline $\begin{array}{c}3^{6} \\
(3 I-44)\end{array}$ & $\begin{array}{c}29 \\
(20-32)\end{array}$ & $\begin{array}{c}24 \\
(17-38)\end{array}$ & $\begin{array}{c}25 \\
(17-37)\end{array}$ & $\begin{array}{c}23 \\
(20-37)\end{array}$ \\
\hline $\begin{array}{c}24 \\
(19-35)\end{array}$ & $\begin{array}{c}20 \\
(19-2 I)\end{array}$ & $\begin{array}{c}23 \\
(16-30)\end{array}$ & $\begin{array}{c}23 \\
(15-28)\end{array}$ & $\begin{array}{c}19 \\
(15-20)\end{array}$ \\
\hline $\begin{array}{c}30 \\
(25-34)\end{array}$ & $\begin{array}{c}\text { I9 } \\
\left(17^{-2 I}\right)\end{array}$ & $\begin{array}{c}2 I \\
(14-25)\end{array}$ & $\begin{array}{c}23 \\
(14-30)\end{array}$ & $\begin{array}{c}18 \\
(14-19)\end{array}$ \\
\hline
\end{tabular}

Table 10. Comparison of thromboplastic activity of platelets from normal and from scorbutic guinea-pigs with serum and adsorbed plasma from normal guinea-pigs

\begin{tabular}{|c|c|c|c|c|c|c|}
\hline \multirow{3}{*}{$\begin{array}{l}\text { Addition to } \\
\text { test system }\end{array}$} & \multirow{3}{*}{$\begin{array}{l}\text { No. of } \\
\text { animals }\end{array}$} & \multicolumn{5}{|c|}{ Substrate clotting time (mean value and range) (sec) } \\
\hline & & \multicolumn{4}{|c|}{ Incubation time } & \multirow[b]{2}{*}{ Minimum } \\
\hline & & $2 \mathrm{~min}$ & $3 \mathrm{~min}$ & $4 \min$ & $5 \mathrm{~min}$ & \\
\hline $\begin{array}{l}\text { Platelets from normal } \\
\text { animals }\end{array}$ & 4 & $\begin{array}{c}I 4 \\
(9 \cdot 5-21)\end{array}$ & $\begin{array}{c}10.5 \\
\left(10.5^{-I I}\right)\end{array}$ & $\begin{array}{c}10.5 \\
(10-11)\end{array}$ & $\begin{array}{c}\text { II } \\
\left(9^{\cdot} 5^{-12}\right)\end{array}$ & $\begin{array}{c}x \circ \\
\left(9^{\cdot} 5^{-11}\right)\end{array}$ \\
\hline $\begin{array}{l}\text { Platelets from scorbutic } \\
\text { animals }\end{array}$ & 3 & $\begin{array}{c}\mathrm{I3} \\
(9-15)\end{array}$ & $\begin{array}{c}9 \\
\left(8 \cdot 5^{-10}\right)\end{array}$ & $\begin{array}{c}10 \\
(9 \cdot 5-1 I)\end{array}$ & $\begin{array}{c}\text { II } \\
\left(9^{\cdot} 5^{-I I}\right)\end{array}$ & $\begin{array}{c}9 \\
(8 \cdot 5-9 \cdot 5)\end{array}$ \\
\hline Saline & - & 47 & $4 I$ & 34 & 35 & 29 \\
\hline
\end{tabular}

Table II. Antiheparin activity of platelets from normal and scorbutic guinea-pigs

Addition to test system (ml)

$\begin{array}{ccccc}\begin{array}{c}\text { Platelets* } \\ \text { from } \\ \text { normal } \\ \text { animals }\end{array} & \begin{array}{c}\text { Platelets* } \\ \text { from } \\ \text { scorbutic } \\ \text { animals }\end{array} & \text { Saline } & \text { Heparint } & \begin{array}{c}\text { Clotting } \\ \text { time } \\ (\mathrm{sec})\end{array} \\ - & - & 0.2 & - & 13.5 \\ \text { O.I } & - & 0 . \mathrm{I} & 0 . \mathrm{I} & 19 \\ - & - & - & 0 . \mathrm{I} & 13.3 \\ & 0 . \mathrm{I} & - & 0 . \mathrm{I} & 13.3 \\ & * \text { c. } \mathrm{I} .5 \times 10^{6} / \mathrm{mm}^{3} . & +\mathrm{I} \mu \mathrm{g} / \mathrm{ml} . & \end{array}$

DISCUSSION

Most of the current knowledge of mammalian blood coagulation has been derived from observations on human blood. In the interpretation of our results we assume that there is a similarity between the guinea-pig and the human test systems. We are not aware of any definitive comparative study, but the reactions of the blood from normal guinea-pigs in the tests are sufficiently similar to those of human blood to warrant tentative interpretation in terms of human blood coagulation theory, at least on a 
qualitative basis. If we are only concerned with finding out whether there is a difference between normal and scorbutic guinea-pigs, the validity of the foregoing assumption is irrelevant since the reference standard for the scorbutic animal is the normal animal. The validity of the assumption is relevant, however, when we attempt to interpret any difference that is found; here reference has to be made to a bloodcoagulation theory based mainly on human blood.

Our investigation indicated some depression of the coagulation reaction of blood from scorbutic guinea-pigs. It was most clearly seen in the group completely deprived of vitamin $\mathrm{C}$ and was evident at the prothrombic and thromboplastic levels. The prolonged plasma one-stage prothrombin times were corrected by serum, but not by adsorbed plasma, from normąl animals. The defect does not, therefore, involve factor $\mathrm{V}$ which is present in adsorbed plasma, or prothrombin which is absent from normal serum.

Factor X (Koller, I955), which may also be identical with the Stuart or Prower factor (Denson, 1958), was not involved as the Stypven time was normal; factor X deficiency is associated with a prolonged Stypven time (Biggs, 1956; Dische, 1958). A deficiency of factor VII (Koller, Loeliger \& Duckert, 195I) appears to be the most likely explanation since this factor is present in serum, but not in adsorbed plasma, from normal animals.

The blood thromboplastin defect cannot be explained by a factor VII deficiency, however, since factor VII does not take part in thromboplastin formation (Ackroyd, 1956). It is therefore necessary to postulate the deficiency of another factor. Both the serum and adsorbed plasma showed decreased thromboplastic activity. It could be caused by a deficiency of plasma thromboplastin antecedent (Rosenthal et al. 1955) or a combined deficiency of antihaemophilic globulin and Christmas factor. It is clear that further work is necessary before the defect can be fully characterized. In contrast to the prothrombic defect, lowered thromboplastic activity was found in only half the scorbutic animals. Interpretation of this fact should be cautious, however, as most specimens were stored for varying periods, and it is well known that samples from patients with a PTA syndrome can revert to normal on storage (Rosenthal et al. 1955; Biggs, Sharp, Margolis, Hardisty, Stewart \& Davidson, 1958).

Ascorbic acid per se played no part in either the prothrombic or thromboplastic defect since, when added in vitro or injected shortly before the animals were bled and killed, it caused no improvement. Likewise, vitamin $\mathrm{K}$ was not directly involved since adequate amounts were provided in the diet and supplementary injections of the vitamin had no effect.

All scorbutic animals examined had haemorrhages in the muscles adjacent to the knees and some also in the viscera. But it has not so far been established whether they were causally related to the coagulation defects. Although the plasma prothrombin times were prolonged, such an increase $(25 \%)$ by itself would not be expected to produce haemorrhage. Likewise, the thromboplastic defect was relatively mild. Although haemorrhage by itself can cause a depression of coagulation factors (Chalmers, Bigelow \& Desforges, I954) this depression occurs only when blood loss is large. It would seem an unlikely explanation, as gross haemorrhage was not observed. 
No definite explanation can be given for the consistent increase in platelets. Fibrinogen is also known to be raised (Marx \& Bayerle, 1943; Howard, 1958), and the two effects may be a secondary response to tissue damage and chronic haemorrhage. It is noteworthy that human platelets are rich in ascorbic acid (Barkhan \& Howard, 1958). As yet, there is no evidence that this high concentration is connected with any haemostatic function. In the present work we have found both the clot-retracting and thromboplastic activities of platelets from scorbutic animals to be normal. It is tempting to speculate that the petechial haemorrhages characteristic of thrombocytopaenic purpura and also of scurvy in man are in some way related. The defect in scurvy has been attributed primarily to vascular alteration (Wolbach \& Bessey, 1942), but platelets may play a more important part in vascular integrity than is at present realized. The nature of the interaction between blood-clotting factors and the vascular wall is a fundamental aspect of haemostasis which is only beginning to be understood (Roos, 1957).

\section{SUMMARY}

I. Some aspects of the mechanism of blood coagulation were investigated in thirty normal and twenty-five scorbutic guinea-pigs.

2. In scorbutic animals, there was an increase in the platelet concentration $(50-80 \%)$ and in plasma one-stage prothrombin times $(25 \%)$. The blood thromboplastic activity was also impaired. Stypven times and the clot retraction and thromboplastic activities of platelets were normal.

3. The prothrombic and thromboplastic defects were found in animals that received no ascorbic acid for 10-23 days or $0.4 \mathrm{mg} /$ day for 100 days, but not in those receiving $0.8 \mathrm{mg} /$ day or more.

4. The defects appeared to be multifactorial but their exact nature was not established. Correction experiments suggested a deficiency of factor VII as well as of a thromboplastic factor or factors of serum and adsorbed plasma.

5. Ascorbic acid injected shortly before death, vitamin $\mathrm{K}$ for several days before death and ascorbic acid in vitro produced no correction.

6. Small haemorrhages, consistently in muscles around the knees (but not intraarticular) and sometimes visceral, were present in all the scorbutic animals. It was not established whether they were causally related to the coagulation defects.

Miss Sheila Tomlin and Mr K. Day gave valuable technical assistance. This work was done during the tenure by P.B. of an Elmore Research Studentship of the University of Cambridge.

\section{REFERENCES}

Ackroyd, J. F. (1956). Brit. F. Haemat. 2, 397.

Barkhan, P. (1957). F. clin. Path. 10, 26.

Barkhan, P., Tomlin, S. C. \& Archer, R. K. (I957). F. comp. Path. 67, $35^{8}$.

Barkhan, P. \& Howard, A. N. (1958). Biochem. F. 7o, I63.

Bell, W. N. \& Alton, H. G. (1954). Nature, Lond., 174, 880.

Biggs, R. (1956). Brit. F. Haemat. 2, 412.

Biggs, R. \& Douglas, A. S. (1953). F. clin. Path. 6, 23. 
Biggs, R. \& MacFarlane, R. G. (1957). Human Blood Coagulation and its Disorders, and ed. Oxford: Blackwell Scientific Publications.

Biggs, R., Sharp, A. A., Margolis, J., Hardisty, P. M., Stewart, J. \& Davidson, W. M. (1958). Brit. $\mathcal{F}$. Haemat. 4, I77.

Chalmers, 'T. C., Bigelow, F. S. \& Desforges, J. F. (1954). F. Lab. clin. Med. 43, 5 I I.

Denson, K. W. (1958). Brit. F. Haemat. 4, 313.

Dische, F. E. (1958). Brit. F. Haemat. 4, 201.

Findlay, G. M. (1921). F. Path. Bact. 24, 446.

Howard, A. N. (1958). Brit. F. Nutr. 12, 346.

Koller, F. (1955). Rev. Hemat. ro, 362.

Koller, F., Loeliger, A. \& Duckert, F. (1951). Acta haemat. 6, I.

Lee, R. E. \& Lee, N. Z. (1947). Amer. F. Physiol. 149, 465.

Marx, R. \& Bayerle, H. (1943). Biochem. Z. 315, 366.

Quick, A. J. (1939). Proc. Soc. exp. Biol., N.Y., 42, 788.

Reid, M. E. \& Briggs, G. M. (1953). F. Nutr. 51, 34x.

Roos, J. (1957). Thrombosis et Diathesis Haemorrhagica, I, 471.

Rosenthal, R. L., Dreksin, H. \& Rosenthal, N. (1955). Blood, 1o, 120.

Sullivan, W. R., Gangstad, E. O. \& Link, K. P. (r943). F. biol. Chem. r51, 477.

Wolbach, S. B. \& Bessey, O. A. (1942). Physiol. Rev. 22, 233.

Wolbach, S. B. \& Howe, P. R. (1926). Arch. Path. I, 1.

\title{
Studies on the in vitro conversion of $\beta$-carotene into vitamin $A$ in tissues from the rat, guinea-pig and sheep
}

\author{
By N. A. WORKER* \\ Biochemistry Department, Massey Agricultural College \\ (University of New Zealand), Palmerston North, N.Z.
}

(Received 6 February 1959-Revised 30 Fune 1959)

It is now generally accepted that parenterally administered carotene, provided it is presented in a suitable physical state, can be effectively converted into vitamin $A$ in the animal body (Bieri \& Pollard, I954; Bieri, r955; Kon, McGillivray \& Thompson, I955; McGillivray, Thompson \& Worker, 1956). In all the experiments of these workers aqueous dispersions of carotene in water-miscible surface-active agents of the Tween type (the polyoxyethylenesorbitans) were used.

The site of conversion of injected carotene has not as yet been determined. Bieri \& Pollard (1954) were the first to demonstrate that conversion of intravenously administered carotene into vitamin A was unaffected by removal of the small intestine, the normal site of conversion after oral administration. Later the same authors noted that in nephrectomized rats, and in rats from which up to $75 \%$ of the liver tissue had been removed, the amounts of vitamin A formed after injection were similar to the amounts formed in intact control rats. Kon et al. (1955) have also provided evidence, though of a more indirect nature, that in rats and rabbits conversion of injected carotene occurs away from the intestine and is independent of the presence of the liver.

Recently attempts have been made, in our laboratory, to locate more precisely the site at which conversion of injected carotene occurs. It has been clearly demon-

* Present address: Ruakura Animal Research Station, Private Bag, Hamilton, N.Z. 